\title{
LOCAL COASTAL GOVERNANCE ASSESSMENT DEVELOPMENT: COASTAL GOVERNANCE FRAMEWORK REPORTING
}

\author{
Raimonds Ernsteins ${ }^{1}$, Dr.habil.paed./Prof.; Maija Stokmane ${ }^{2}$, MSc.biol. and Arturs Pudans ${ }^{3}$, \\ BSc.env.sc. \\ $1,2,3$ University of Latvia, Riga, Latvia
}

\begin{abstract}
Coastal governance practice at the local level in Latvia has various shortages and the reasons behind that are several, including, that the coastal municipalities have neither sufficient coastal information and understanding, nor integrative planning tradition and active stakeholder's participation experience. The aim is to study to what extent and how municipal coastal governance (MCG) has been developed and accordingly performed towards effective pro-environmental and pro-coastal policies, thus analysing the coastal governance dimensions - governance content, process and its documents, main stakeholders understanding and contribution - in Jurmala municipality as a chosen coastal pilot territory, since being especially sensitive area at the Latvian coastline. The summary results of case study research (document studies, observation and stakeholder's interviews) suggest, that the municipality still has limited focus on sustainable coastal governance - in general, underdeveloped internationally acknowledged integrated coastal management (ICM) implementation approaches and related requirement on various basic ICM capacities development. There are neither specially designed coastal planning and management system (ICM sectorial/cross-sectorial approach), nor well developed ICM integration into statutory municipal development planning process and products (ICM integration approach). Existent MCG is based on long existing traditional approach of former and formal sector-based municipal development planning with limited cross-sectorial perspectives and linking. Taking into account also climate change adaptation challenges, new understanding and new approaches, including mixed ICM approach and also, eventually, a range of innovative coastal governance instruments. The study is done in the framework of the research-and-development approach aimed also to develop recommendations for the improvement of the local coastal governance practise, e.g. testing of MCG framework and also testing to be pre- and post-planning document - Municipal Coastal Governance Outlook - as designed for MCG overview and assessment with later public discussion and stakeholder MCG agreement as well as for integrative planning as could be serving as basic missing integration instrument.
\end{abstract}

Key words: coastal governance report; socio-ecological system; integrated coastal management; environmental governance dimensions.

JEL codes: Q20, Q57, Q58

\section{Introduction}

Nowadays, a lot of contradictions and conflicts of interest develop in coastal areas and therefore attract particular attention, and its management should be especially carefully planned. Latvian local municipalities, that border the Baltic Sea, should protect and manage one of the largest national treasures - the coastal area (almost $500 \mathrm{~km}$ of coastline, not only, but mainly sandy beach areas) is defined as area of national interest, where the preservation of coastal joint natural and cultural heritage should be balanced with the promotion of economic development, including tourism (Sustainable Development Strategy of Latvia, 2030). However, also internationally, the amount and the availability of the necessary coastal information is often insufficient and also knowledge on complex coastal systems is still limited for main coastal stakeholders, especially at the local government level (Stojanovic, 2007; O'Hagan, 2009; Klingsheim, 2011; Ernsteins et al. 2011; Kalpakis, 2018), therefore having difficulties to carry out integrated coastal management (ICM) approach (Ballinger et. al., 2008; Deboudt, 2012; Portman, 2012; Buono, 2015; Ernsteins, 2017) as developed and prescribed internationally (EC, 2002). In Latvian coastal territories there is the lack

\footnotetext{
${ }^{1}$ Raimonds Ernsteins Tel.: +371 29476620, e-mail: raimonds.ernsteins@lu.Iv

2 Maija Stokmane Tel.: +371 22161440, e-mail: ms08165@students.lu.Iv

3 Arturs Pudans Tel.: +371 29209429, e-mail: art.pudans@gmail.com
} 
of all type capacities at the local (municipal) level (Ernsteins, 2011; Coastal Spatial Plan, 2016) in coastal exploration/assessment, policy/planning, management and monitoring, actually, for the whole coastal governance cycle and also instruments (Ernsteins, 2017; Kaulins, 2017). Also, at the national level, even there are recently ongoing possibilities to support municipalities at least within the proposed framework of the coastal public infrastructure as the first and main priority for national municipal coastal governance (MCG), however the second priority announced, being good coastal governance, have also some national impetus but lacking far behind at the local coastal development and environmental protection work (Coastal Spatial Strategy, 2011; Coastal Infrastructure Plan, 2016). Previous ICM related studies in Latvia (Ernsteins, 2011 and 2017; Kaulins, 2017; Coastal Infrastructure Plan, 2016) are leading to the recognition, that there are limited ICM developments at all governance levels (national, regional planning and local level), particularly, missing both initial ICM preconditions - identification and assessment of the complex coastal socio-ecological resources and services, including development of coastal municipal monitoring (Lontone et. al., 2017; Kaulins et. al., 2018), as well as, coastal governance structural integration into the statutory political and territorial development planning process and documents, especially at the local level (Ernsteins et. al., 2017a and 2017b). Coastal territories in Latvia need to be more knowledgably and systemically, participatory and adaptably governed.

The governance of the coastal areas should be considered as a governance of a complex socioecological systems (SES) and situation urgency requests to use research-and-development framework (R\&D) applications (Breton, 2006; Hopkins, 2012; Kaulins et. al., 2017) also in Latvian local coastal municipalities. The possible perspectives for the MCG in Latvia might be the development and application of nationally/locally innovative instruments (Breton, 2006; Ballinger, 2009; Thetis, 2011; Ernsteins, 2017b; Kalpakis, 2018; ), esp. cost-effective ones, e.g. municipal monitoring with mandatory public monitoring part, and, accordingly, coastal governance reports and the integration instruments for ICM type development planning/management process and its products/documents etc. (Ernsteins et. al., 2011; Kudrenickis et. al., 2016; Kaulins et.al., 2017; Pommere et. al., 2018). During recent research-and-development (R\&D) studies, mentioned developments have been elaborated within National Research grant SUSTINNO (2014-2018) and also further tested during BaltCoast project (2015-2018) conducted in the Salacgriva rural coastal municipality with financial support of EU BONUS program and Latvian national co-funding. Research results were complemented by the coastal science-policy interface related recommendations, e.g. to design MCG system proposal, based on governance segments, content and process dimensions; including, set of governance instruments, especially collaborative communication instruments; mixed ICM applications perspective in general etc. (Lontone, 2017; Ernsteins, 2020). Current research described now represents next round of mentioned MCG approbations and design studies.

Already in 2008-2009, specialists from the University of Latvia developed the first national level ICM indicator system proposal for Latvia, but later on - also for the local coastal level (Ernsteins et al. 2011 and 2017). The first local level sustainability indicator system proposal in Latvia for the whole territory of the coastal municipality was developed for Saulkrasti municipality (2013) indicator system being approved by municipal council for the evaluation of municipal Sustainable Development Strategy (statutory strategic planning document, required at all governance levels in Latvia) implementation. Following, the first full scale measurement/assessment of this working indicator system has also already been carried out for the municipality, designing and developing also first of a kind in Latvia - Sustainability Outlook as monitoring and reporting system 
instrument for municipal sustainable development governance in Latvia (Ernsteins et al. 2017; Kaulins et al. 2018). This experience is to be further developed, modelled and piloted, also during Jurmala coastal case study research, for the development and testing of the Coastal Governance reporting (Outlook) of Jurmala city, in order to serve eventually as a missing ICM status and integration instrument.

\section{Piloting Jurmala municipality - enclosed coastal strip area along the Baltic Sea}

The pilot and model territory chosen for the present study was the municipality of Jurmala city, semi-urban area being by its size $\left(100 \mathrm{~km}^{2}\right)$ as well as by the number of its inhabitants (almost 60 000 ) the largest resort city on the coast of the Baltic Sea visited by more than a hundred thousand tourists every year. The city, being just $25 \mathrm{~km}$ from Riqa, the capital city of Latvia, actually, is located on a kind of narrow (even only $380 \mathrm{~m}$ at Majori railway station) and long stretched peninsula. This location is formed, by the river Lielupe coast meandering along city $(30 \mathrm{~km})$ from its southern part, and, from Northern part, by seaside at the very bottom of Baltic Sea Riga Bay with around $25 \mathrm{~km}$ long coastal beach, being famous as one of the few white sand beaches in Europe (Fig. 1). Besides, being rich with various natural resources, including six specially protected nature territories occupying approximately $38 \%$ of the city, dune pine forests, sulphide-containing mineral waters and mud actively used in Jurmala resort, which started as early as in the beginning of $19^{\text {th }}$ century, also having diverse coastal cultural-historical resources, Jurmala as the only city in Latvia has officially granted the status of a resort and a healthy city. In the same time, city is threatened by high anthropological pressure, what may lead to the problems with unique coastal health and other resources, ecosystem services, and, Jurmala as coastal and environmentally sensitive municipality, has been stressing importance of environmental protection.

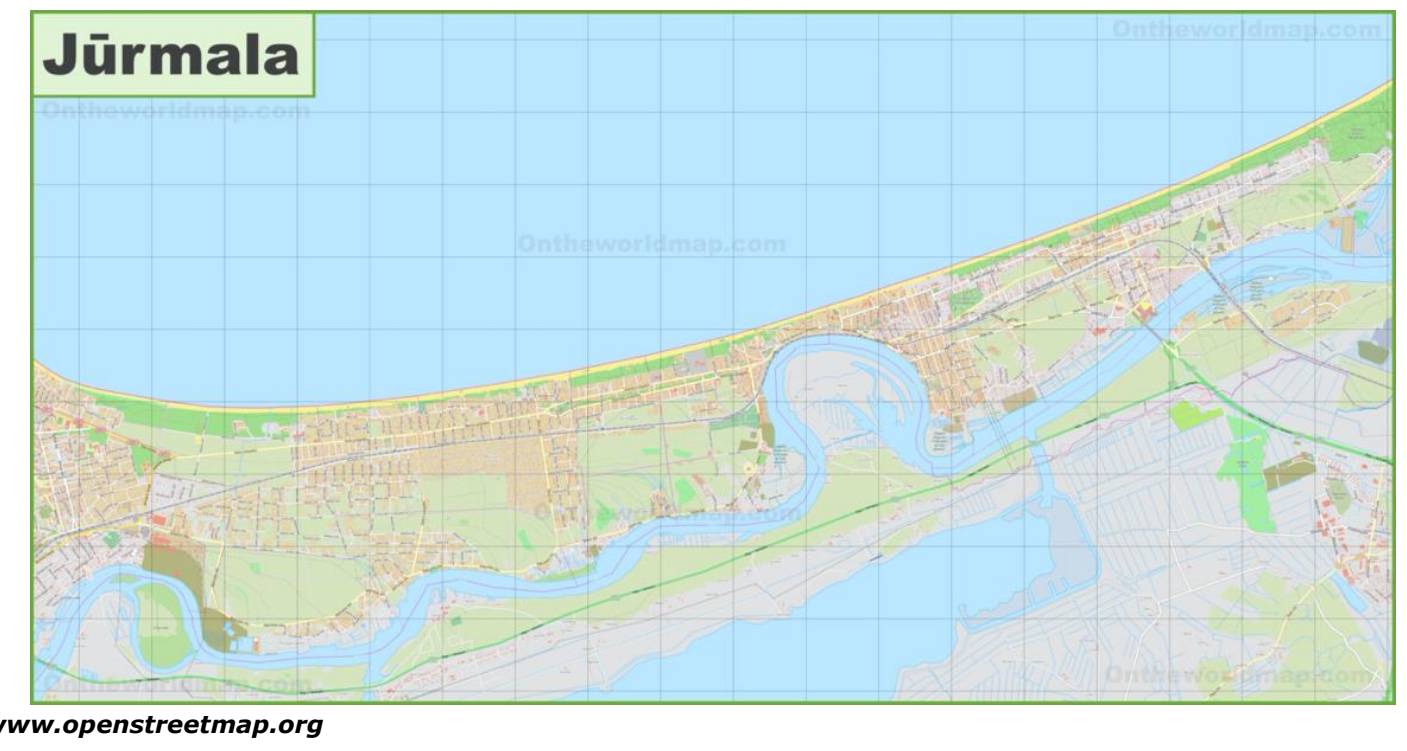

Source:

Fig. 1. The general map of Jurmala city location on the Baltic Sea coast

\section{Methodological framework for coastal governance studies}

The aim of this R\&D study is to assess the irregular complex situation of the environmental and coastal governance at the local municipal level as well as to develop coastal action policy proposals and recommendations for the chosen pilot territory of Jurmala municipality and all its main target groups together. Research object is coastal governance process and it is necessary to clarify to what extent and how both, municipal environmental and coastal governance, have been developed and accordingly performed now towards effective pro-environmental and pro-coastal policies and best 
ICM practise. Methodological coastal governance analytical framework to be applied for this study is structured according to all the triple complementary governance dimensions' system governance content, process (incl. documents) and its realization instruments as well as stakeholders' segments (incl. understanding and contribution) - adopted for local governance level (Ernsteins et.al., 2017b). The collaboration R\&D planning with Jurmala municipality was oriented to find out the main deficiencies and subsequently develop recommendations for the improvement of the whole situation of the coastal governance, eventually designing coastal governance system and process guidelines at the later stage of this study. Subsequently, R\&D study is also aiming to design and develop, to apply and initially test an innovative pre- and post-planning document - the Municipal Coastal Governance Outlook (MCG Outlook) for the Jurmala.

Besides the pre-study of the previous ICM investigations carried out in the coastal territories and also best available practice in Latvia as well as in other countries, relatedly, the main tasks of the present study were: (1) to recognize and study the main developments and deficiencies of the coastal governance main segments (constituting of the main stakeholder groups) and their interactivity (who in ICM); (2) to assess the coastal governance content development as the current coastal socioecological system status and, most importantly also its governance impetus and impacts on this situation (what in ICM); (3) to evaluate coastal governance process, esp. as design and implementation of governance instruments' groups - political and legislative instruments, institutional and administrative, also planning instruments, as well as infrastructure and technological, economic and financial, also communication instruments (how in ICM); (4) by analysing the mentioned coastal governance sectors, segments and process integration into governance framework for pilot municipality to develop recommendations, incl. MCG Outlook document.

\section{Research-and-development project frame}

The Case Study Research (CSR) methodology, being framed via Research-and-Development approach, was used for Jurmala city as model municipality - complementary application of several research methods to get complex system study and overview of temporary phenomenon document studies, stakeholder interviews, coastal site observations. These studies were comprised of two complementary parts for the first stage of the R\&D project - environmental governance studies and coastal governance studies, realized in such a sequence with slight overlapping. Second stage then was on using both approaches and sector information gathered for its complementary integration into the development of MCG Outlook.

Comparative analysis between those two sectors seemed to be perspective when looking towards MCG and taking into account comparative similarity of both to be integrative realized environmental governance and coastal governance sectors, but already long ago statutory established, however never perfect, experience of environmental governance with whole set of instruments - legal, planning, infrastructure, financial, communication and, particularly, also institutional sectorial instruments, e.g. in Jurmala municipality having Development and Environmental Commission, Environmental Dept., municipal Water, Heating etc. companies and other environmental related structure units/organizations. Sustainable cross-dimensionally developed environmental governance sector in coastal municipality would obviously cover also the most of coastal governance cross-sector, and such application approach could be seen as one pragmatically perceived scenario for MCG development to be realized by mutual integration of both sectors, 
particularly, when having long experience authoritative municipal Environmental department (e.g. Ventspils international harbour based city municipality), taking lead role and organizing most of necessary coastal governance functions coordination work and at various administration levels and organizations. Also Jurmala municipality have had such disciplinary (sector based) Environmental governance development experience after establishing of Environmental Dept. since 1990-ties and approving Environmental Policy Plan since 2002 etc. possessing several other sectorial instruments, being at the time for only top five cities in Latvia.

Detailed CSR studies started with the inspection and analysis of all the municipal statutory and sustainability/environmental/coastal issues related documents at all local administration level and sectors - political and legal, development planning, management regulations/practice documents, but also in the relation and about all main stakeholder groups and activities, as well as for the whole coastal municipality territory in case of environmental governance and coastal governance, starting from 150/300 m coastal dune protection belt up to $5 \mathrm{~km}$ limited economic activity belt and the whole municipality territory (Protection Belt Law, 1997). That was complemented with observation study along the main coastal strip institutional, infrastructure and management related territories, objects and organizations. Finally, 25 deep semi-structured interviews were conducted with representatives of all local stakeholders, being legally designated and/or being involved with municipality both environmental and coastal issues and grouped by governance segments (Ernsteins et al. 2017):

- Municipality / City council administration segment (elected deputies, employees of municipality);

- National administration segment institutions (employees of the Ministry of Environmental Protection and Regional Development, the State Environmental Service and the Nature Conservation Agency, incl. Kemeri National Park, partially also within Jurmala municipal borders);

- Corporative (business) segment (different municipality based producing/services entrepreneurs);

- Mediator segment, in particular (representatives of the media, formal/non-formal education and non-governmental organizations, science representatives);

- Inhabitants of coastal city, local householders - were not interviewed, but utilized different secondary sources, esp. bi-annual municipal questionnaires on local development evaluation.

\section{Coastal governance framework reporting approach - Outlook}

On the basis of all the information obtained during studies, including available general data banks at the municipality, the preparation of the initial version of the Jurmala Coastal Governance Outlook as pre/post planning document was carried out, striving for still non-traditional SES multi-disciplinary application, and, especially and mainly oriented towards initial status and potential development assessment of to be established coastal governance framework (system). This initial MCG Outlook document was designed and structured being based methodologically on three main governance dimensions' approach, including governance segments (structured all main stakeholder groups), governance contents (cross-sectorial thematic) and governance process instruments, but altogether in their interlinked sectorial-integrative ICM complex frame (Ernsteins et al. 2017). This is represented here as table of contents for the MCG Outlook document: Part 1. Overview: An overall characterization of the municipality's sustainable development; Part 2. Development of the MCG: The formal place of the MCG in the overall development planning process and statutory and other planning documents of the municipality; Part 3. Supervision of the MCG: The elements of the MCG monitoring system within the municipality's planning documents; Part 4. MCG stakeholders: Characterization of the interest groups and their governance; Part 5. MCG content: Characterization 
of all MCG four sectors and cross-sectors of social-ecological system, their governance; Part 6. MCG process: Characterization of all MCG six groups of instruments (especially, set of coastal communication instruments); Part 7. Summary: Sectoral versus integrative MCG development and Recommendations.

MCG Outlook design model included the following man constituents (Ernsteins, 2017b and 2020): (1) MCG content framework was based on application of costal governance content four systemically integrated sector's model - Coastal governance and communication; Coastal infrastructure environment (including coastal technical, spatial planning environment); Coastal socioeconomic environment; Joint coastal nature and cultural environment. (2) MCG process instruments framework was based on application of all main and complementary six coastal oriented governance instrument group's model - political and legislative instruments, institutional and administrative, also planning instruments, as well as infrastructure and technological, economic and financial, also communication instruments; (3) MCG stakeholder segments framework was based on application of complementary five governance segments model - state environmental/coastal institutions (esp. regional agencies); local municipal institutions (incl. administration, service and utility companies); Jurmala municipality located business companies; mediators segment (incl. non-governmental organizations (NGOs), formal/ informal educators; media and various experts representing a science sector); and local inhabitants. Drafted MCG Outlook document version was subduing to the initial approbation process - expert discussions, approach and content testing via stakeholder interviews. Detailed approbations are planned for latter stages of the project, including focus groups and stakeholder seminars.

\section{Jurmala case study research - coastal governance studies}

Jurmala municipality has a particularly great responsibility for the conservation and sustainable use of the coastal multidimensional resources, especially in circumstances when the integration version of ICM approach has been chosen, which requires a very high level of coordination of all management services and instruments.

Table 1

\section{SWOT analysis: coastal governance components in Jurmala municipality}

\begin{tabular}{|c|c|}
\hline Strengths & Weaknesses \\
\hline $\begin{array}{l}\text { - A very important natural, cultural-historical, economic-tourism related } \\
\text { resource - the sea coast with its wide sandy beaches; } \\
\text { - Natural resources- sulphide-containing mineral waters and sludge - } \\
\text { are one of the few deposits of these resources in a temperate climate } \\
\text { zone; } \\
\text { - Municipality has partially or indirectly integrated some coastal aspects } \\
\text { into its mandatory development planning documents; } \\
\text { - Municipality has developed several voluntary thematic planning } \\
\text { documents (for example, "A vision for the development of Kemeri area", } \\
\text { "Resort concept of Jurmala city"), which partly include also the coastal } \\
\text { issues; } \\
\text { - The municipality has established some indicators which are partly } \\
\text { related with the coast, such as the number of tourists, revenue from } \\
\text { tourism services etc. } \\
\text { - The infrastructure instruments have been quite successfully used- the } \\
\text { necessary recreation infrastructure is well-established in the coastal area } \\
\text { (beach, dunes, forests/nature parks); } \\
\text { - Several of the specially protected nature territories have been } \\
\text { established directly in the coastal area; } \\
\text { - There are developed multi-nominations in the program "The Blue flag } \\
\text { movement for the beaches and small harbour". }\end{array}$ & $\begin{array}{l}\text { - There are many different regular municipal statutory } \\
\text { commissions/committees, but none is specialized on the coastal issues. } \\
\text { - There is no separate and SES based chapter about the coast/governance in } \\
\text { any on the pre-and planning documents of coastal municipality; } \\
\text { - The municipality has not prepared a separate thematic planning document } \\
\text { about the coast; } \\
\text { - In all of the mandatory development planning documents there is } \\
\text { noticeable some dis-balance stressing specially supported economic interests } \\
\text { in the coastal zone compared to the interests of the nature environment; } \\
\text { - The coastal monitoring does not really occur; } \\
\text { - The municipality has not developed any separate indicators (or indicator } \\
\text { system) which could be used in the coastal monitoring; } \\
\text { - The establishment and development of the wide tourism infrastructure } \\
\text { within the coastal natural areas will increase the anthropogenic pressure on } \\
\text { the fragile coastal ecosystems; } \\
\text { - Not all of the governance instrument groups which are at the disposal of } \\
\text { the municipality are used or widely used for the coastal management; } \\
\text { - The involvement of different stakeholders-governance segments (for } \\
\text { example, residents and NGOs) in the development municipal coastal zone is } \\
\text { limited; }\end{array}$ \\
\hline Opportunities & Threats \\
\hline $\begin{array}{l}\text { - The closer cooperation with other coastal municipalities (including the } \\
\text { Latvian Coastal Municipalities association), and the collaborative } \\
\text { development and implementation of the coastal policy planning } \\
\text { documents; } \\
\text { - Involvement and active participation in the spatial planning of the } \\
\text { Baltic Sea; } \\
\text { - Cooperation with the national interest groups for the development of } \\
\text { environmental communication, the attraction of the external sources of } \\
\text { finance, and the adoption of the world's best practice; } \\
\text { - Expanding the cooperation with the Nature Conservation Agency in } \\
\text { order to care better for the nature environment in the coastal area; }\end{array}$ & $\begin{array}{l}\text { - The lack of modern environmental/coastal governance and increased } \\
\text { number of tourists and visitors may result in depletion/degradation of the } \\
\text { coastal natural and cultural resources; } \\
\text { - The possibility that coastal municipalities will continue to have inadequate } \\
\text { political and financial support from the state for coastal protection and } \\
\text { development issues; } \\
\text { - The lack of general public awareness in Latvia about the coastal problems } \\
\text { because of the incomplete reflection of the coastal issues in the various } \\
\text { information sources; }\end{array}$ \\
\hline
\end{tabular}


- Active participation in the national/international research and development projects on the coastal issues;

- Attraction of the external financial resources to solve the coastal

problems (including the state support, EU funds etc.).

Without support of any thematic coastal assessment and/or planning document in the municipality that would provide guidelines and supervision in approaching ICM. The overall assessment of the Jurmala municipality's three main coastal governance dimensions (sectors, segments and instruments) and their components was done by using a SWOT (Strengths-Weakness-OpportunitiesThreats) analysis framework (Table 1).

\section{Discussion and recommendations}

Previous coastal governance or related studies suggest, that most of Latvian coastal municipalities to particular extent have limited integration of the coastal aspects into their statutory development plans. At the municipal level, there is not only a lack of coastal governance capacity (in rural municipalities also general planning-management capacities), but especially a lack of information about the complex coastal socio-ecological system. Also the link between the national and the local level planning documents and practices is insufficient, and therefore the provision of the ICM approach remains under threat in the coastal zone of Latvia, actually, coastal governance is comparatively incomplete in Latvia.

Summarizing environmental governance studies in short we are coming to several assessment results, understandings and, subsequent, conclusions: (1) governance content environmental related sectors are assessed in terms of content - data/information, however, not at the same level and within the same updating term; moreover, not all system information is accumulated, systematized and accessible, including for integrated use in the planning and management process; (2) governance segments - depending on particular topic, but with limited pro-activity and basically limited public involvement in the decision-making process have been observed; the target groups are not sufficiently aware of their role and the necessity to cooperate; (3) governance process and instruments - municipality have almost the whole set of diverse instruments, both integrative and sectoral, but it was not observed that all environmental management instruments are actively used, including in the complementary manner;

After R\&D studies done in Jurmala municipality, especially stakeholders, experts and environmental agencies interviews conducted, there are to be recognized general conditions, still traditionally known overall integration deficiencies, both internal and external for environmental governance realization practice quality, and, actually, directly similarly to be recognized for coastal governance as also proved during current studies. Main internal conditions for mentioned not sufficient environmental governance implementation are: it's not fully integrated into the statutory planning documents; management practices are not sufficiently integrated into the planning/practice of Jurmala City Council departments and organizations; there is little scope for co-operation between municipal departments, departments and non-municipal organizations/stakeholders. Subsequently, it is recommended to look for functional audits and revision/update of related regulations, job descriptions and annual individual/collective work plans of structural units of the municipality in order to integrate the whole content, process and instrumental issues of the environmental (also coastal) management sector, its sub-sectors, also sustainable development cross-sectors as systemically properly as possible, to regulate and also institutionalize horizontal and vertical 
cooperation among structural units as far as possible. Relatedly, main stakeholders and, especially experts/specialists, recognize also the following main external conditions: not sufficient legal requirements of integration principle and consistent implementation of existent requirements, lack of methodological and guidance materials, training and communication from the sectorial Ministry of Environmental Protection and Regional Development, their regional structures in particularly, how to integrate environmental (and coastal) management; non-regular and organized effective pressure from the general public and mediators, including NGOs, on politicians and managers that environmental (coastal) management particularly needs to be more active; also public media has relatively little pressure and practical information on the issue. Summarizing, the combination of

legal pressure with methodological support, still best practice developments and complementary use of environmental communication instruments (Ernsteins, 2017a; Lontone, 2017), as well as, all types of stakeholder cooperation or better collaboration and building of various partnerships and networks could be again and again recommended as overall problemsolving frame.

Jurmala as coastal and environmentally especially sensitive municipality has been step-wise developing various environmental protection and management planning studies and documents incl. starting from municipal Environmental Policy Plan (2002-2010), but later developing Sustainable Energetics' Program (2013), Water Resources Protection Plan (2016), as well as coastal resort, tourism, river harbour etc. development plans, done with limited/formal public collaboration, as well as commissioned several coastal issues related mono-thematic studies. However, MCG studies are proving, that all main local stakeholders, including municipality employees and decision makers, still have limited information and understanding on the whole complex coastal socio-ecological system, and, have been not deciding either on ICM sector approach oriented process and document in Jurmala as per ICM national planning recommendations from Europe (EC, 2002) or procedural realization of ICM integration approach, according to the main eight ICM policy principles and instruments etc. recommendations (EC, 2002). Also ICM or MCG or alike terminology haven't been employed by municipal development policies and practice in general in Latvia, instead applying traditional sectorial development policy/planning approach and terminology to view and plan coastal system via separate and limitedly interconnected planning sectors, e.g. beach infrastructure, nature protection, tourism, building etc sectors.

Existent MCG has several limitations to be seen as directly related to the coastal policy and administration as well as normative and planning capacities, especially, in circumstances when the MCG integration version chosen, but this requires a very high level of coordination of all instruments. Having all these coastal SES and its governance challenges, municipality step-wise continuously works with MCG further implementation, but climate change and other additional inside/outside challenges would require more pro-active development steps and renewed, even just nationally/locally new innovatives, mix of governance instruments (Ballinger, 2008; Stojanovic, 2007; Ernsteins, 2017b) into their mixed development and complementary application. At least preplanning/resource document (MCG Outlook or alike), which could be serving for more detailed knowledge-based coastal science-policy-practice (Lontone, 2017) understanding and eventual complex integration into both - planning processes and documents of municipal statutory development planning as well as any voluntary thematic (tourism, culture heritage, etc) planning too (Thetis, 2011; Hopkins, 2012; Ernsteins, 2017a). 
This initial Environmental Governance Outlook document was designed and structured being based methodologically on tthree main governances' dimensions' approach, but altogether in their interlinked sectorial-integrative ICM complex frame and first version was prepared, which already in this first stage of the project gives a new systemic overview and cumulative information about the coastal governance situation in the municipality, but which is going to be publicly tested, supplemented and updated during the next stage of current R\&D project to be eventually serving as a useful auxiliary document in the coastal planning process in the municipality of Jurmala. The fact that this approach is very convenient to use and easy-to-understand for both municipal employees and other target groups, could be a key to success of this approach, therefore its use should be seriously considered when re-designing ICM type further development.

\section{Conclusions}

1) Besides good number of coastal related planning, infrastructure etc. instrument developments in Jurmala municipality, incl. existing governance instruments and their application, not all aspects related with the coastal environment and its governance have been integrated within statutory planning (and/or voluntary) and, subsequently, municipal practice (incl. monitoring and stakeholder's collaborations) - coastal governance is comparatively limitedly integrated into municipal development governance. Municipality step-wise continuously works with MCG further implementation, but climate change adaptation and other additional inside/outside challenges would require more pro-active development steps and renewed, even just nationally/locally new, instrumental and other innovations, mix of coastal governance approaches and instruments

2) It could be recommended also to all coastal municipalities of Latvia, especially for rural coastal municipalities, also to the city of Jurmala as the largest resort city on the coast of the Baltic Sea and one of the most popular tourism/recreation destinations in Latvia, but at the same time being bio-geographically sensitive territory - it is necessary to consider, elaborate and systemically use the coastal governance framework for MCG planning/management development as minimum as networking application of all main and complementary coastal oriented governance instrument groups - political and legislative instruments, institutional and administrative, also planning instruments, as well as infrastructure and technological, economic and financial, also communication instruments.

3) In piloting of innovative in Latvia municipal coastal pre-/post- planning document, the Municipal Coastal Governance Outlook, it was recognized that its design based on the three basic governance dimensions - coastal governance sectors, governance segments and governance instruments - is also comparatively easy to be understood and utilized by all main stakeholder groups since answering most important questions regarding MCG: by Whom, What and How is needed to be done for coastal governance system establishment. MCG Outlook could serve as basic missing integration instrument to take necessary account of coastal social-ecological system and its governance conditions for designing/renewing of statutory municipal development planning and documents as well to be used as mandatory integrative requirement for any other voluntary (sectorial/thematic) planning processes and documents, e.g. climate change, coastal contingency, health/resort, tourism etc. planning. 


\section{Bibliography}

1. Ballinger, R, Cummins, V., O'Hagan, A.M., Philippe, M. (2008). The Point of COREPOINT: Improving Capacity for Integrated Coastal Zone Management in North West Europe. COREPOINT Report. p. 81

2. Breton F. (2006). Report on the Use of the ICZM Indicators from the WG-ID of EC: A Contribution to the ICZM Evaluation. European Environment Agency, 63.

3. Buono, F., Soriani, S., et. al. (2015). The Difficult Road to Integrated Coastal Zone Management Implementation in Italy: Evidences from the Italian North Adriatic Regions. Ocean and Coastal Management, $114,21-31$.

4. Deboudt, P. (2012). Testing Integrated Coastal Management in France. Ocean Coastal Management, 57, 6278.

5. Recommendation of the European Parliament and Council Concerning the Implementation of Integrated Coastal Zone Management in Europe (2002). Brussels, 2002/413/EC

6. Ernsteins, R., Kaulins, J., Lice, E., Stals, A. (2011). Integrated Coastal Management for Local Municipalities in Latvia: Sustainability Governance and Indicator System, WIT Transactions on Ecology and Environment, 149, pp. 29-40.

7. Ernsteins, R., Kudrenickis, I., Kaulins, J., Lontone-Ievina, A. (2017a). Pro-Environmental Municipal Governance Developments in Latvia: Sustainability and Integration Principles in Practice. Proceedings of The International Scientific Conference, Vilnius Gediminas Technical University, Vilnius, Lithuania, May 2017, 308317pp.

8. Ernsteins, R., Kudrenickis, I., Lontone-Ievina, A., Kaulins, J., Urtans, A. (2017b) Municipal Sustainable Coastal Governance: Participatory Approaches for System Analysis and for Local Monitoring Development. WSEAS Transactions on Environment and Development, Vol. 13, pp 276-290

9. Ernsteins, R., Lagzdina, E., Kudrenickis, I. Lontone, A., (2020) Municipal Coastal Governance System Developments in Latvia: Governance Segments, sectors and instruments. Economic Science for Rural Development Conference Proceedings. Latvian University of Life Sciences and Technologies, Jelgava, Latvia, May 2020 (in print)

10. Hopkins, S., Bailly, D. et al. (2012). A Systems Approach Framework for the Transition to Sustainable Development: Potential Value Based on Coastal Experiments, Ecology and Society, Vol. 17, Issue 3, p.39.

11. Kalpakis V., Kokkos N., Pisinaras V., Sylaios G. (2018). An Integrated Coastal Zone Observatory at Municipal Level: the Case of Kavala Municipality, Greece. Journal of Coastal Conservation, 23, 149-162.

12. Kaulins, J., Ernsteins, R., Kudrenickis, I., Lontone-Ievina, A., Zilniece, I. (2017). Municipal Thematical and Territorial Indicator Systems for Sustainable Socio-Ecological Coastal Governance. Proceedings of The International Scientific Conference, Vilnius Gediminas Technical University, Vilnius, Lithuania, May 2017, 318329pp.

13. Kaulins, J., Ernsteins, R., Kudrenickis, I. (2018) Monitoring and Reporting System for Municipal Sustainable Development Governance in Latvia: Sustainability Outlook. Economic Science for Rural Development Conference Proceedings. Latvian University of Agriculture, Jelgava, Latvia, May 2018, 129-137. pp.

14. Klingsheim J. M. (2011). Norwegian Policies in ICZM and Requirements for Data and Methods, Adapting to Climate change. BLAST - Bringing Land and Sea Together, 1-20.

15. Lontone, A., Ernsteins, R., Lagzdina, E., et. al. (2017). Local Coastal Governance: Science-Policy Interface and Municipal Monitoring. Proceedings. 13th International MEDCOAST Congress on Coastal and Marine Sciences, Engineering, Management and Conservation, MEDCOAST 2017, pp. 105-116

16. National Long-Term Public Infrastructure Thematic Plan for the Coastal Area of the Baltic Sea (2016). Ministry of Environmental Protection and Regional Development, Republic of Latvia (Coastal Infrastructure Plan 2016)

17. O'Hagan A.M., Ballinger R. (2009). Coastal Governance in North West Europe: An Assessment of Approaches to the European Stocktake. Marine Policy, 33(6), 912-922.

18. Pommere I., Osniece K., Lontone-Ievina A., Ernsteins R. (2018). Municipal Integrated Coastal Management: Local Participatory Multi-thematical Monitoring Development. Journal of Social Sciences, Regional Formation and Development Studies, pp. 106-118.

19. Portman, M. E., Esteves, L.S., Le, X.Q., Khan, A.Z. (2012). Improving Integration for Integrated Coastal Zone Management: An Eight Country Study. Science of the Total Environment, 439, 194-201.

20. Protection Zone Law. Republic of Latvia, Parliament Saeima on 05.02.1997.

21. Stojanovic, T.A. (2007) Guidelines for Implementing Local Information Systems at the Coast. COREPOINT and Cardiff University, Cardiff. p. 35

22. Strategy for Coastal Spatial Development for 2011-2017 (2011). Ministry of Environmental Protection and Regional Development, Republic of Latvia (Coastal Spatial Strategy 2011)

23. Sustainable Development Strategy of Latvia until 2030 (Republic of Latvia, Parliament Saeima on 10.06.2010).

24. Thetis (2011). Analysis of Member States Progress Reports on Integrated Coastal Zone Management (ICZM): Final Report. European Commission - DG Environment, 357. 